\title{
Assessment of two persistent bioaccumulative toxicants in the UNESCO protected river of Osun-Osogbo, Nigeria
}

\author{
Emmanuel O. Akindele ${ }^{1 *}$, Godwin O. Olutona ${ }^{2}$, Oyeshina G. Oyeku ${ }^{3}$ and Akinkunle V. Adeniyi ${ }^{4}$
}

\begin{abstract}
Introduction: Osun River dissecting the Osun-Osogbo Sacred Grove, though inscribed on the World Heritage List, has been rarely assessed for biodiversity values or ecotoxicology. In this study, we investigated the concentrations of $\mathrm{Cu}$ and $\mathrm{Zn}$ in the benthic sediments and two dominant gastropod species (Melanoides tuberculata and Lanistes varicus) of the Osun River. Benthic sediment and gastropod samples were collected on quarterly basis from June 2015 to March 2016 along the longitudinal stretch of the river. Dry samples were digested and analysed for Cu and Zn using the atomic absorption spectrophotometry.

Results: With the exception of September sampling period, the two metals recorded higher values in the animals than in the sediments. Cu $(1.23 \pm 0.81 \mu \mathrm{g} / \mathrm{g})$ was much lower $(p<0.01)$ than zinc $(6.29 \pm 2.15 \mu \mathrm{g} / \mathrm{g})$ in the benthic sediments. In the same vein, Cu was significantly lower $(p<0.01)$ than Zn in both species. Both metals recorded much lower values than their average concentrations in the Earth's crust as well as the recommended limits for freshwater life. Comparatively, L. varicus recorded higher bioaccumulation factor than M. tuberculata.

Conclusions: Findings from this study suggest that both metals posed no toxicological risk to the freshwater system of Osun River. Concentrations of both metals in the sediments as well as their accumulation factors in both gastropod species were indicative of an unimpacted freshwater system.
\end{abstract}

Keywords: Accumulation, Benthic sediments, Contamination, Ecotoxicology, Heavy metals, Freshwater gastropods

\section{Introduction}

Persistent bioaccumulative toxicants (PBTs) are ubiquitous despite bans or regulated use and are highly toxic and extremely persistent in aquatic environments (Muir and de Wit 2010; Ray and McCormick-Ray 2014). They include the heavy metals and organo-metal compounds. PBTs persist in aquatic environments owing to their resistance to physical, chemical and metabolic breakdown and consequent accumulation in sediments where organisms feed. Studies have shown that uptake of heavy metals by the aquatic organisms is either via semi-permeable body surface or gut (Rainbow 2007). Through feeding, such toxicants concentrate in their fatty tissues and overtime the body-load can reach a concentration greater than ambient

\footnotetext{
* Correspondence: eoakindele@oauife.edu.ng

'Department of Zoology, Obafemi Awolowo University, lle-lfe, Nigeria

Full list of author information is available at the end of the article
}

water. Consequently, the organisms themselves become toxic (Ray and McCormick-Ray 2014).

In the UNESCO-protected environment of Osun River, two gastropod species (i.e. Melanoides tuberculata Müller and Lanistes varicus Müller) have been reported as keystone species among invertebrate assemblage of the river system (Akindele et al. unpublished). Thus, this study seeks to assess the level of two PBTs (i.e. $\mathrm{Cu}$ and $\mathrm{Zn}$ ) in the river system which drains the Osun-Osogbo Sacred Grove, a UNESCO World Heritage Site (WHS). The site, though selected as a WHS based on cultural values, has recently been described as a biodiversity hotspot for plants and some animal groups (Akinpelu and Areo 2007; Onyekwelu and Olusola 2014). Motivation for this study was born out of the fact that life, both in the riparian and freshwater systems of the WHS, will depend to a large extent on the health status of the river system therein. Furthermore, if biodiversity/natural value of the WHS must be conserved, it is very important to monitor 
the health status of its river system. In spite of the regional and global significance of this section of Osun River as a WHS, there has been no toxicological or biomonitoring study conducted therein. Towards bridging this information gap, $\mathrm{Cu}$ and $\mathrm{Zn}$ were selected for the study in view of the fact that they have been ranked top in terms of toxicity among eightheavymetals (i.e. $\mathrm{Cu}>\mathrm{Cd}>\mathrm{Zn}>\mathrm{Pb}>\mathrm{Ni}>\mathrm{Fe}>\mathrm{Mn}>\mathrm{Al}$ ) in a biomonitoring study using $M$. tuberculata (Shuaimi-Othman et al. 2012). Moreover, neither the study area nor its immediate upstream section is being explored for mining activities or exposed to industrial activities, to suggest high concentrations of metals like $\mathrm{Cd}, \mathrm{Pb}, \mathrm{Hg}$ or $\mathrm{Ni}$ in the basin. However, dumping and burning of domestic wastes as well as the use of agricultural pesticides for farming characterize the riparian corridor of the grove's immediate upstream and downstream sections. High concentrations of both metals in freshwater systems have been widely associated with these human-induced stressors, among other sources (Adewunmi et al. 1996; Gimeno-Garcia et al. 1996); hence, the selection of $\mathrm{Cu}$ and $\mathrm{Zn}$ is logical for this ecotoxicological study. Furthermore, high natural levels of the selected metals for this study have also been reported as being indicative of higher concentrations of other metals like $\mathrm{Pb}, \mathrm{Cd}$ or Hg (Government of Saskatchewan 2008).

Heavy metals are metallic elements that have a relatively high density with an atomic weight greater than 20 (Kibria et al. 2010). They fall under the category of persistent bioaccumulative chemicals, and some of them are endocrine-disrupting and carcinogenic (Kibria et al. 2016). Heavy metals are naturally released into freshwater environments through weathering of rocks and soils and are important for biochemical and physiological processes of the biota. However, elevated concentrations in sediments and sufficient accumulations in the biota have also been reported to pose a great hazard to freshwater ecosystems and toxicological risk for humans (Chapman and Kimstach 2006; Dachs and Mejanelle 2010; Ray and McCormick-Ray 2014). Among the heavy metals, $\mathrm{Cu}$ and $\mathrm{Zn}$ are essential for physiological and biochemical processes but are also capable of accumulating in sediments and impacting freshwater biota at elevated concentrations (Campbell and Tessier 1996; Environment Canada 1998). They are highly toxic to plankton, invertebrates and various larvae at high concentrations (Ray and McCormick-Ray 2014). It has been recommended that $\mathrm{Cu}$ and $\mathrm{Zn}$ concentrations in the benthic sediments of a freshwater system do not exceed the limits of 35.7 and $123 \mu \mathrm{g} / \mathrm{g}$, respectively, in order to sustain the biodiversity of its benthic macroinvertebrates and the entire biota (Environment Canada 1998; Canadian Councils of Ministers of the Environment 1999a, b). The ecotoxicological impacts of $\mathrm{Cu}$ and $\mathrm{Zn}$ on benthic macroinvertebrates cannot be over-emphasized. For instance, in ecotoxicological study of River Niagara, Ontario, gastropods were less abundant at the sections of the river with mean concentration (i.e. $52.2 \mu \mathrm{g} / \mathrm{g}$ ) beyond the recommended limit of $\mathrm{Cu}$ than the sections where mean concentration $(26.0 \mu \mathrm{g} / \mathrm{g})$ fell below the limit. In a similar study on the Bay of Quinte (Lake Ontario), species richness of Ephemeroptera, Plecoptera and Trichoptera was much lower at sites where mean concentration of $\mathrm{Zn}(293 \mu \mathrm{g} / \mathrm{g})$ exceeded the recommended limit than at sites where mean concentration $(119 \mu \mathrm{g} / \mathrm{g})$ fell below the limit (Jaagumagi 1988). In view of the foregoing, the current study seeks to bridge the information gap on the ecotoxicology of this historic African river. This was with a view to providing baseline information on toxicity of metals in the river and finding out if their concentrations were within safe limits for sustenance of freshwater life.

\section{Methods}

Collection of benthic sediments and gastropod specimens Field study was conducted from June 2015 to March 2016, on quarterly basis. The samples were collected from ten stations within the study area (Fig. 1). Two replicate samples were collected; one each from the littoral and sub-littoral zones. A grab sampler was used to collect sediment samples at a depth of $0-10 \mathrm{~cm}$ at the littoral (within $2 \mathrm{~m}$ from the shoreline) and sub-littoral (2-5 m from the shoreline) zones. The samples of $M$. tuberculata and $L$. varicus were detached from substrata (e.g. rocks, pebbles, mud) and/or collected from the grab samples. Three samples each of $M$. tuberculata and L. varicus of comparable size were collected from each site for analysis. In each case, replicate samples were homogenized to represent each station. Efforts were made to return pebbles and stones to their original positions and only the required numbers of gastropod samples were collected due to conservation ethics.

\section{Sediment digestion procedure}

Sediment samples were first air-dried in the laboratory, after which they were digested according to the procedures prescribed by the AOAC (1990). One gram of sediment was measured using an analytical weighing balance and placed in a $250 \mathrm{ml}$ beaker. Subsequently, $10 \mathrm{ml}$ of concentrated $\mathrm{HNO}_{3}$ was added, and then the mixture was boiled for 30-45 min in order to oxidize all easily oxidisable organic matter. The heated mixture was allowed to cool after which $5 \mathrm{ml}$ of $70 \% \mathrm{HClO}_{4}$ was then added, and the mixture was boiled gently until dense white fumes appeared. The mixture was allowed to cool again, after which $20 \mathrm{ml}$ of distilled water was added and the mixture was re-boiled to release any fume. The mixture was left to cool again and then filtered using Whatman no. 42 filter paper. Filtrate was diluted to $25 \mathrm{ml}$ with distilled water. 


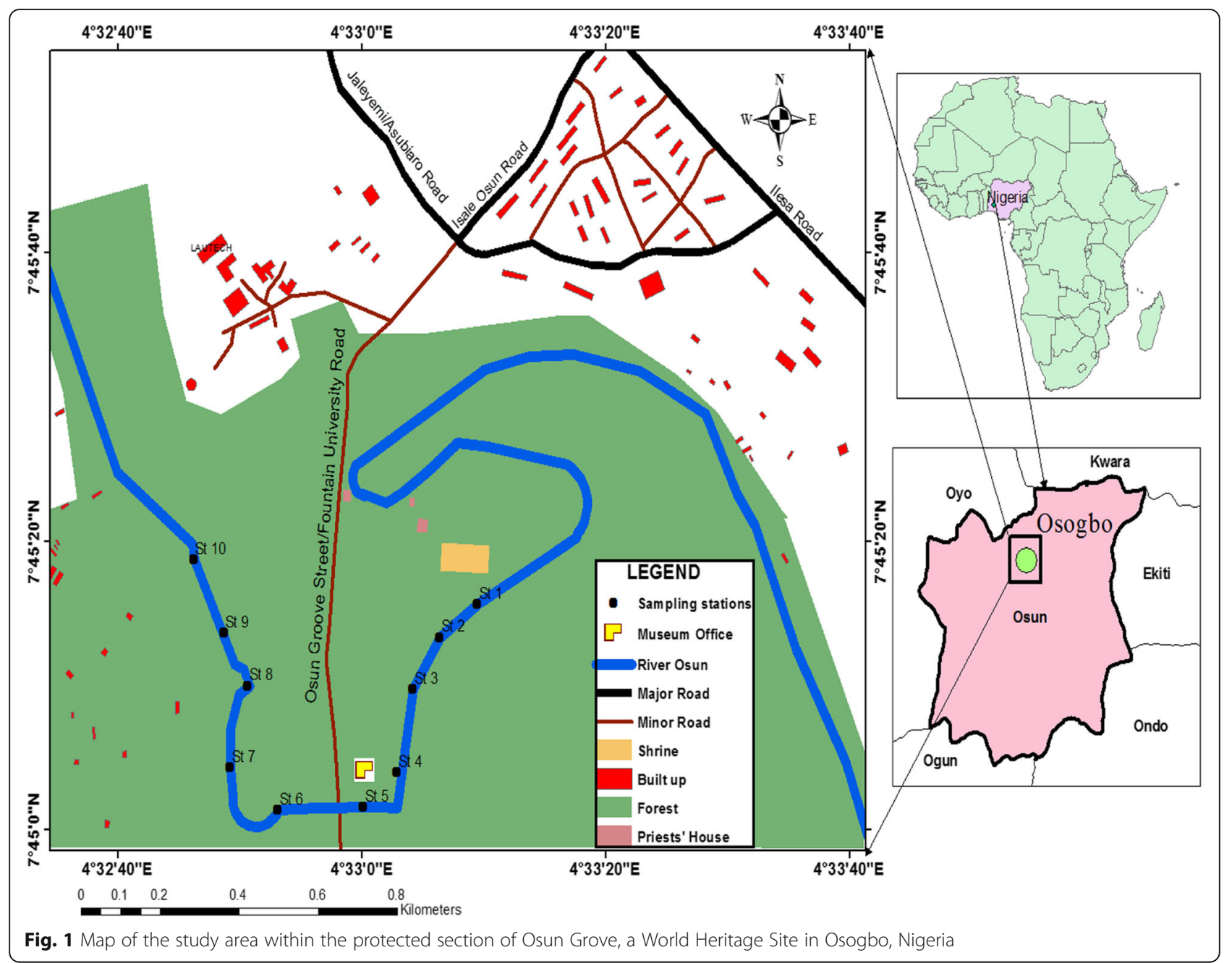

\section{Digestion of gastropod samples}

Visceral mass of each gastropod was removed from its shell and dried in the oven at $65^{\circ} \mathrm{C}$ until a constant weight was obtained. Thereafter, replicate samples of each species from the same site were homogenized by grinding them into a powdery form using mortar and pestle and transferring them later into already labelled universal bottles. The nitric acid $\left(\mathrm{HNO}_{3}\right)$ digestion method was employed in the digestion of the samples. Half a gram of the sample was digested with $5 \mathrm{ml}$ concentrated $\mathrm{HNO}_{3}, 1 \mathrm{ml} \mathrm{H}_{2} \mathrm{O}_{2}$ and $1 \mathrm{ml}$ of $\mathrm{HClO}_{4}$, and heated until white fumes of perchloric acid was formed, and about $1.5-2 \mathrm{ml}$ of the mixture remained. The mixture was allowed to cool, after which $5 \mathrm{ml}$ of distilled water was added, and then heated to dissolve precipitates. The digested samples were cooled and diluted to $25 \mathrm{ml}$ mark with distilled water and stored until analysis for metal contents (Onwuka 2005).

\section{Quality control measures and extraction procedure}

Matrices spiked experiment were also carried out to ascertain the precision of analytical method employed in this study. Two samples each weighing $0.5 \mathrm{~g}$ were placed into different beakers. One of the samples was spiked with $100 \mu \mathrm{g} / \mathrm{g}$ of the mixed standards while the second sample was unspiked. The two pre-weighed samples were digested using the same digestion procedure enumerated above. The digested and filtered sample was transferred into $25 \mathrm{ml}$ volumetric flask and made up to mark with distilled water. The concentrations of the selected trace metals $(\mathrm{Cu}$ and $\mathrm{Zn}$ ) were determined by subjecting the two samples to atomic absorption spectrophotometry (AAS) analysis. The percentage recovery for each metal was then calculated. The detection limits of $\mathrm{Cu}$ and $\mathrm{Zn}$ were 0.0045 and $0.0033 \mathrm{ppm}$, with wavelengths of 324.8 and $213.9 \mathrm{~nm}$, respectively.

\section{Data analysis}

Contamination factor was calculated during each sampling period as the ratio of metal concentration in the sediment to its average value in the Earth's crust (Forstner and Wittmann 1981). Accumulation factor on the other hand was a ratio of metal concentration in each gastropod 
species to metal concentration in the corresponding benthic sediment (Shuaimi-Othman et al. 2012).

Obtained data were analysed using non-parametric statistical tools since the sample size was neither sufficiently large enough nor the distribution normal. Mann-Whitney $(U)$ test was employed to test for significance between the two metals at each sampling period $(n=10)$, while Kruskal-Wallis $(H)$ tool was employed to test for significance in temporal variation $(n=4)$ and spatial variation $(n=10)$.

\section{Results}

\section{Concentrations of $\mathrm{Cu}$ and $\mathrm{Zn}$ in the benthic sediments}

The results of the recovery analysis of the metals (in range) were $89.8-92.5 \%$ for $\mathrm{Cu}$ and $95.8-98.7 \%$ for $\mathrm{Zn}$. These values are adjudged acceptable; thus, the results are reliable. The spatial variations in the concentrations of $\mathrm{Cu}$ and $\mathrm{Zn}$ are shown in Fig. 2. There was neither a distinct pattern in the spatial concentrations of the two metals nor a statistical significance $(H=12.79, p>0.05$ for $\mathrm{Cu}$ and $H=10.62, p>0.05$ for $\mathrm{Zn}$ ). The overall mean spatial concentration of $\mathrm{Zn}(6.29 \pm 2.15 \mu \mathrm{g} / \mathrm{g})$ was however significantly higher $(p<0.001)$ than $\mathrm{Cu}$ concentration $(1.23 \pm 0.81 \mu \mathrm{g} / \mathrm{g})$. Temporally, $\mathrm{Cu}$ concentrations ranged from $1.16 \pm 0.26$ to $2.41 \pm 0.76 \mu \mathrm{g} / \mathrm{g}$ with June and September recording the lowest and highest values $(H=12.81, p<0.01)$, respectively. $Z n$ recorded the lowest $(3.17 \pm 1.11 \mu \mathrm{g} / \mathrm{g})$ and highest $(8.97 \pm 1.97 \mu \mathrm{g} / \mathrm{g})$ values in March and September, respectively, $(H=10.85, p>0.05)$. $\mathrm{Cu}$ concentrations in the study period were in the following order: June $<$ March $<$ December $<$ September, while those of $\mathrm{Zn}$ were as follows: March $<$ June $<$ December $<$ September. Throughout the sampling period and at all the stations, mean values of $\mathrm{Zn}$ were significantly higher than those of $\mathrm{Cu}(U=6.5, p<0.01$ in June; $U=8, p<0.01$ in September; $U=2, p<0.01$ in December; and $U=8$, $p<0.01$ in March).

\section{Concentrations of $\mathrm{Cu}$ and $\mathrm{Zn}$ in the gastropods}

Figure 3 shows the spatial concentrations of $\mathrm{Cu}$ and $\mathrm{Zn}$ in M. tuberculata. The gastropod showed neither a distinct pattern nor a significant difference in the concentrations of both metals among the stations $(H=7.73, p>0.05$ for $\mathrm{Cu} ; H=5.69, p>0.05$ for $\mathrm{Zn}$ ). The mean spatial concentration of $\mathrm{Cu}(2.32 \pm 0.77 \mu \mathrm{g} / \mathrm{g})$ was however significantly lower $(U=1, p<0.01)$ than that of $\mathrm{Zn}(6.26 \pm 1.43 \mu \mathrm{g} / \mathrm{g})$. Specifically, $\mathrm{Cu}$ was also significantly lower $(p<0.01)$ in the gastropod throughout the sampling periods. Temporal concentrations of $\mathrm{Cu}$ showed no significant difference $(H=5.50, p>0.05)$ and ranged from $2.07 \pm 0.37$ to $2.98 \pm 0.34 \mu \mathrm{g} / \mathrm{g}$, with June and December recording the lowest and highest values, respectively. Zn concentrations showed a different trend in temporal variation with the highest value $(8.11 \pm 1.35 \mu \mathrm{g} / \mathrm{g})$ recorded at the beginning of the sampling regime (June) while the lowest $(4.57 \pm 0.82 \mu \mathrm{g} / \mathrm{g})$ was recorded at the end of the regime (March) $(H=5.68, p>0.05)$.

Both metals showed neither significant difference $(H=6.38, p>0.05$ for $\mathrm{Cu}$ and $H=6.50, p>0.05$ for $\mathrm{Zn})$ nor a distinct pattern among the sampling stations in the case of L. varicus (Fig. 4). Comparative mean values of the two metals in the stations showed the same trend as in the sediment and $M$. tuberculata, with $\mathrm{Cu}$ recording $2.49 \pm 0.18 \mu \mathrm{g} / \mathrm{g}$ and $\mathrm{Zn} 10.39 \pm 0.57 \mu \mathrm{g} / \mathrm{g}$ $(U=0, p<0.01)$. Analysis of both metals in $L$. varicus at each sampling period showed the same pattern as in $M$. tuberculata, i.e. much higher value recorded for $\mathrm{Zn}$ and there were significant differences in all occasions $(U=11, p<0.01$ in June; $U=5, p<0.01$ in September; $U=0, p<0.01$ in December; and $U=7, p<0.01$ in March). In terms of temporal variation, the lowest mean

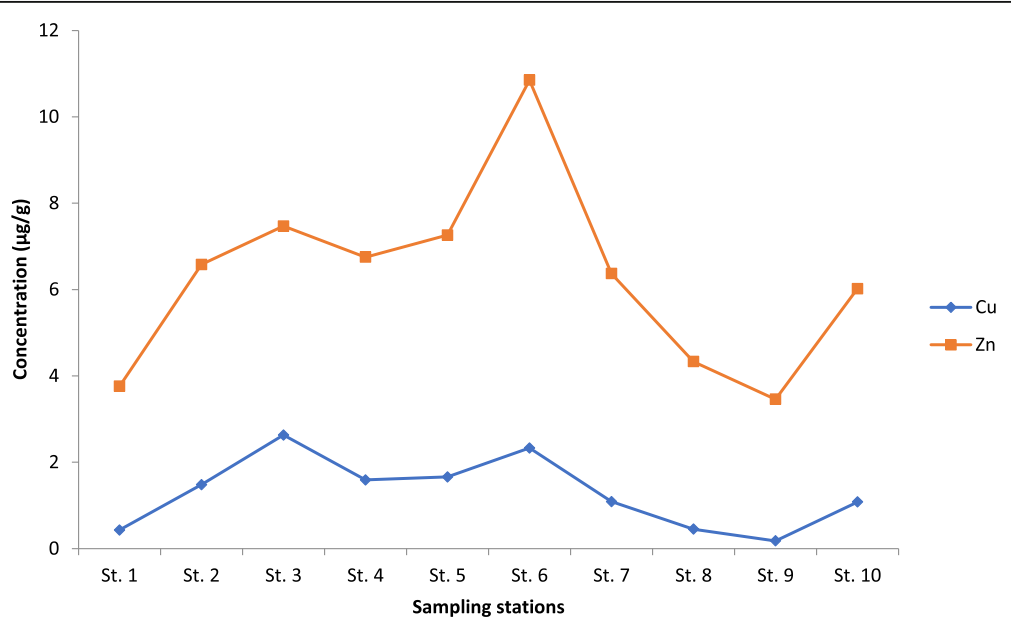

Fig. 2 Concentrations of Cu and Zn in the sediments of River Osun, Osogbo, Nigeria (June 2015-March 2016) 


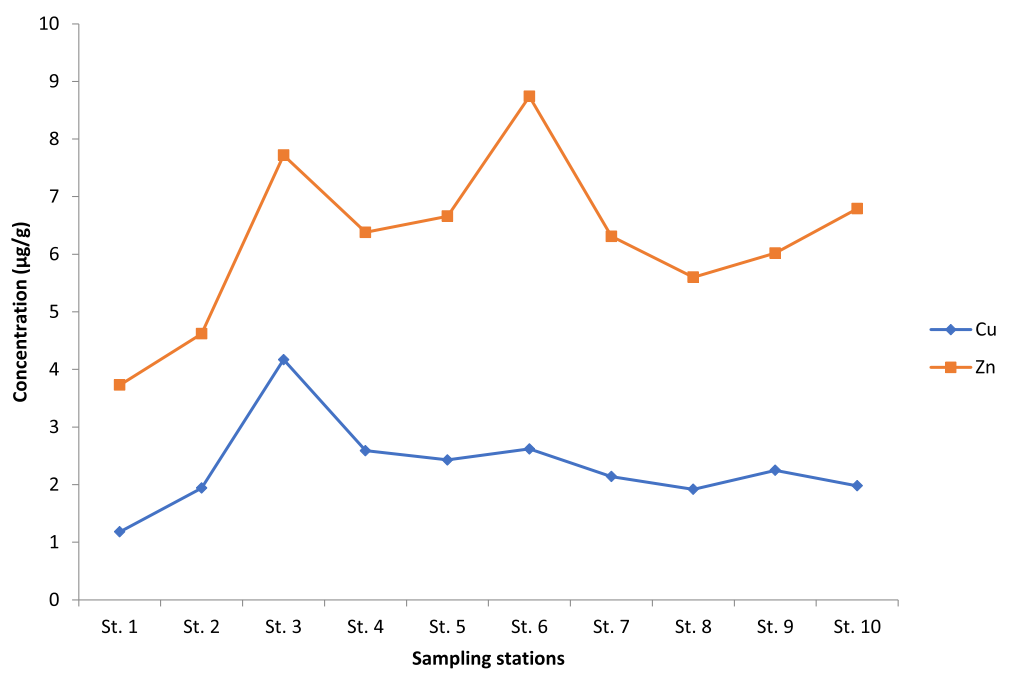

Fig. 3 Concentrations of Cu and Zn in M. tuberculata of River Osun, Osogbo, Nigeria (June 2015-March 2016)

concentration of $\mathrm{Cu}$ was recorded in September $(1.87 \pm 0.55 \mu \mathrm{g} / \mathrm{g})$ while the highest was in June $(3.11 \pm 0.45 \mu \mathrm{g} / \mathrm{g})$, though with no significant difference $(H=4.64, p>0.05)$. Zinc recorded lowest concentration in June $(9.09 \pm 1.37 \mu \mathrm{g} / \mathrm{g})$ and the highest in December $(12.51 \pm 0.43 \mu \mathrm{g} / \mathrm{g})(H=4.09, p>0.05)$.

Comparative assessment of each metal in both gastropod species indicates that $\mathrm{Cu}$ recorded higher concentration in M. tuberculata in June and March, while it recorded higher values in September and December for Lanistes varicus. None however showed significant difference $(p>0.05)$. Conversely, $\mathrm{Zn}$ recorded a higher value in $L$. varicus than in $M$. tuberculata throughout the sampling regime, although significant difference $(U=24, p<0.05)$ was only observed in September.

Accumulation factors of the metals in both gastropod species during the study period are shown in Table 1. Cu was higher in the tissues of $M$. tuberculata than in the sediment throughout the sampling period, except in September 2015, and its accumulation factor was highest in December 2015. Zinc was lower in $M$. tuberculata than in sediment in September and December 2015, and its highest accumulation factor was recorded in March 2016. With the exception of September 2015 when $\mathrm{Cu}$ was higher in the sediment than in L. varicus, all other periods recorded higher $\mathrm{Cu}$ values in the animal. Zinc recorded higher values in the animal than the sediment throughout the sampling periods. However, there were no significant differences $(p>0.05)$ between the accumulation of $\mathrm{Cu}$ and $\mathrm{Zn}$ in both species, and neither was there a significant difference $(p>0.05)$ in the accumulation of metals between the two species.

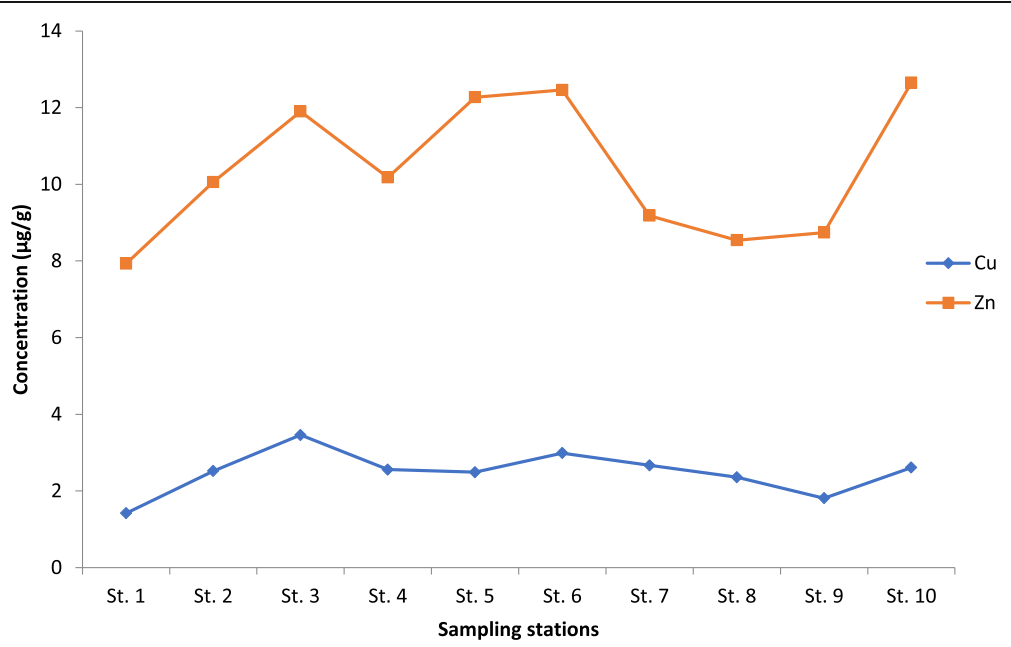

Fig. 4 Concentrations of Cu and Zn in L. varicus of River Osun, Osogbo, Nigeria (June 2015-March 2016) 
Table 1 Concentrations of Cu and Zn in the benthic sediment and two dominant gastropod species of River Osun and their accumulation factors

\begin{tabular}{|c|c|c|c|c|c|c|}
\hline \multirow[t]{2}{*}{ Period } & \multicolumn{2}{|l|}{ Sediment $(n=10)$} & \multicolumn{2}{|c|}{ M. tuberculata $(n=10)$} & \multicolumn{2}{|l|}{ L. varicus $(n=10)$} \\
\hline & $\begin{array}{l}\text { Mean } \pm \text { s.e. }(\mu \mathrm{g} / \mathrm{g}) \\
\text { of } \mathrm{Cu}\end{array}$ & $\begin{array}{l}\text { Contamination } \\
\text { factor }\end{array}$ & $\begin{array}{l}\text { Mean } \pm \text { s.e. }(\mu \mathrm{g} / \mathrm{g}) \\
\text { of } \mathrm{Cu}\end{array}$ & $\begin{array}{l}\text { Accumulation } \\
\text { factor }\end{array}$ & $\begin{array}{l}\text { Mean } \pm \text { s.e. }(\mu \mathrm{g} / \mathrm{g}) \\
\text { of } \mathrm{Cu}\end{array}$ & $\begin{array}{l}\text { Accumulation } \\
\text { factor }\end{array}$ \\
\hline June 2015 & $1.16 \pm 0.25$ & 0.02 & $2.07 \pm 0.37$ & 1.79 & $3.11 \pm 0.45$ & 2.68 \\
\hline September 2015 & $2.41 \pm 0.76$ & 0.05 & $2.11 \pm 0.68$ & 0.88 & $1.87 \pm 0.55$ & 0.78 \\
\hline December 2015 & $1.36 \pm 0.31$ & 0.03 & $2.98 \pm 0.34$ & 2.19 & $2.67 \pm 0.38$ & 1.96 \\
\hline \multirow[t]{2}{*}{ March 2016} & $1.21 \pm 0.77$ & 0.02 & $2.13 \pm 0.40$ & 1.76 & $2.32 \pm 0.31$ & 1.92 \\
\hline & $\begin{array}{l}\text { Mean } \pm \text { s.e. }(\mu \mathrm{g} / \mathrm{g}) \\
\text { of } Z \mathrm{n}\end{array}$ & $\begin{array}{l}\text { Contamination } \\
\text { factor }\end{array}$ & $\begin{array}{l}\text { Mean } \pm \text { s.e. }(\mu \mathrm{g} / \mathrm{g}) \\
\text { of } Z n\end{array}$ & $\begin{array}{l}\text { Accumulation } \\
\text { factor }\end{array}$ & $\begin{array}{l}\text { Mean } \pm \text { s.e. }(\mu \mathrm{g} / \mathrm{g}) \\
\text { of } Z \mathrm{n}\end{array}$ & $\begin{array}{l}\text { Accumulation } \\
\text { factor }\end{array}$ \\
\hline June 2015 & $6.05 \pm 0.96$ & 0.09 & $8.11 \pm 1.35$ & 1.34 & $9.09 \pm 1.37$ & 1.50 \\
\hline September 2015 & $8.96 \pm 1.37$ & 0.13 & $5.51 \pm 0.89$ & 0.61 & $9.4 \pm 1.41$ & 1.05 \\
\hline December 2015 & $6.96 \pm 1.03$ & 0.10 & $6.84 \pm 0.83$ & 0.98 & $12.51 \pm 0.44$ & 1.79 \\
\hline March 2016 & $3.17 \pm 1.11$ & 0.05 & $4.57 \pm 0.81$ & 1.44 & $10.56 \pm 1.34$ & 3.33 \\
\hline
\end{tabular}

\section{Discussion}

Aside the naturally occurring $\mathrm{Cu}$ and $\mathrm{Zn}$ in the Earth's crust, these metals can also be introduced into aquatic systems principally through aerial deposits and surface runoff (Canadian Councils of Ministers of the Environment 1999a, b). In this study, the temporal concentrations of the metals seem to follow the annual trend in terms of precipitation, runoff and flow velocity (Akindele et al. unpublished). The highest values of both $\mathrm{Cu}$ and $\mathrm{Zn}$ in the sediments were recorded in September, a period when rivers in the geographical region of the study area are usually at their annual peak in terms of discharge due to runoff (Akindele and Adeniyi 2013).

Despite the heightened anthropogenic influence of the rainy season, values of both metals in the sediments were much lower than their average values in the Earth's crust throughout the sampling period. While the average values of both metals in the Earth's crust have been put at $70 \mu \mathrm{g} / \mathrm{g}$ $\mathrm{Zn}$ and $50 \mu \mathrm{g} / \mathrm{g} \mathrm{Cu}$ (Malle 1992; Hedrick 2001), Zn concentrations ranged from 0.767 to $15.391 \mu \mathrm{g} / \mathrm{g}$, while $\mathrm{Cu}$ ranged from 0.041 to $8.204 \mu \mathrm{g} / \mathrm{g}$ in the sediments. The concentration difference between the two metals also suggests that they followed the Earth crust's trend (i.e. $\mathrm{Zn}>\mathrm{Cu}$ ) and were most likely not largely influenced by anthropogenic impacts. Furthermore, the mean values of both metals $(1.16 \pm 0.25-2.41 \pm 0.76 \mu \mathrm{g} / \mathrm{g} \mathrm{Cu}$ and $3.17 \pm 1.11-$ $8.96 \pm 1.37 \mu \mathrm{g} / \mathrm{g} \mathrm{Zn}$ ) were much lower than previous reports on a number of Nigerian freshwater sediments. For instance, Adekoya et al. (2006) recorded $\mathrm{Cu}$ ranging from $5.75 \pm 0.95$ to $8.57 \pm 2.44 \mu \mathrm{g} / \mathrm{g}$ and $\mathrm{Zn}$ ranging from $38.70 \pm 3.26$ to $53.54 \pm 3.99 \mu \mathrm{g} / \mathrm{g}$ in the sediments of three different rivers in Lagos, Nigeria. In Ibadan, Southwest Nigeria, mean values of $\mathrm{Cu}$ and $\mathrm{Zn}$ in Alaro stream ranged from $13.50 \pm 3.25$ to $19.63 \pm 2.82 \mu \mathrm{g} / \mathrm{g}$ and $3.02 \pm 0.57$ to $12.82 \pm 2.91 \mu \mathrm{g} / \mathrm{g}$, respectively, (Tyokumbur and Okorie 2014). Iwegbue et al. (2007) also recorded higher values of
$\mathrm{Cu}$ (i.e. $3.38 \pm 1.72 \mu \mathrm{g} / \mathrm{g}$ ) and $\mathrm{Zn}$ (i.e. $12.46 \pm 4.56 \mu \mathrm{g} / \mathrm{g}$ ) in the sediments of Ase River, a tributary of Forcados River in the Niger Delta of Nigeria, than reported in this study. In the far northern part of Nigeria, close to the Chad Basin, Akhan et al. (2010) reported $\mathrm{Cu}$ ranging from $26.32 \pm 0.02$ to $51.32 \pm 0.01 \mu \mathrm{g} / \mathrm{g}$ in the sediments of River Ngada of Maiduguri, while $\mathrm{Zn}$ ranged from $132.03 \pm 0.20$ to $163.45 \pm 0.06 \mu \mathrm{g} / \mathrm{g}$. These values suggest that the concentrations of $\mathrm{Cu}$ and $\mathrm{Zn}$ in the sediments of this section of Osun River were much lower than the case was, in comparable freshwater systems in Nigeria. It is also worthy to note that while some previous ecotoxicological reports of Nigerian freshwaters indicated $\mathrm{Cu}$ and $\mathrm{Zn}$ pollution, concentrations of the metals in the protected section of Osun River were far less than the USEPA limits (i.e. 18.70 and $124.0 \mu \mathrm{g} / \mathrm{g}$, respectively) or the Canadian Environmental Quality Guidelines (35.7 and $123 \mu \mathrm{g} / \mathrm{g}$ ) for freshwaters (USEPA 1996; Canadian Council of Ministers of the Environment 1999a, b). Regulated human activities, large expanse of riparian forest, low metal concentration input from the upstream/catchments and dilution by organic matter could have all contributed to keeping the metals at very low concentrations within the basin. Furthermore, the basin is well underlain with carbonaceous rocks which are indicative of Ca richness and concomitantly, low toxicity of metals. Friedrich et al. (1996) have asserted that the toxicity of $\mathrm{Cu}$ and $\mathrm{Zn}$ is inversely proportional to Ca concentration.

Sediments and gastropods recorded their highest values of the metals at different periods in this study. While sediment concentrations of both metals were at their peak in September, M. tuberculata and L. varicus recorded highest concentrations of the metals in their tissues much later, after September. High volume of freshwater through rainfall which characterized the September sampling period could concurrently dilute the concentrations of metals in their tissues. In terms of accumulation factor, L. varicus seemed 
to be more predisposed to metal accumulation than $M$. tuberculata. This may be attributed to the much wider aperture opening of $L$. varicus and consequent larger surface area exposed to the environment. Furthermore, $L$. varicus grows much bigger (about 10 times) than $M$. tuberculata of comparable age, thus confirming that toxicants accumulate in direct proportion with body size, as opined by several authors (e.g. Muir and de Wit 2010; Ray and McCormick-Ray 2014).

Ecotoxicological studies of Nigerian freshwater systems have focused largely on the use of ichthyofauna as the study organisms (e.g. Uzairu et al. 2009; Onwuemesi et al. 2013; Wangboje and Ikhuabe 2015), with very rare studies on benthic macroinvertebrates. Considering the sessile nature of most benthic macroinvertebrates, they could provide more reliable information (than mobile fishes) on the toxicology of lotic systems in particular. In very rare ecotoxicological studies of gastropods in Nigeria, Tyokumbur and Okorie (2014) reported that $\mathrm{Cu}$ ranged from $33.86 \pm 1.23$ to $89.23 \pm 7.34 \mu \mathrm{g} / \mathrm{g}$ in $M$. tuberculata of Alaro stream in Southwest Nigeria while $\mathrm{Zn}$ ranged from $12.10 \pm 2.12$ to $66.35 \pm 1.29 \mu \mathrm{g} / \mathrm{g}$. Adewunmi et al. (1996) reported a very high value of $\mathrm{Cu}$ $(2353 \mu \mathrm{g} / \mathrm{g})$ in Lymnaea natalensis Krauss of OwenaOndo Reservoir of Southwestern Nigeria in May and attributed it to the wide use of $\mathrm{CuSO}_{4}$ as fungicide by farmers in the area. Elsewhere in Africa and in a biomonitoring study of the Nile River, concentrations of $\mathrm{Cu}$ ranged from 330.77 to $1530.86 \mu \mathrm{g} / \mathrm{g}$ in Lanistes carinatus (Abd El Gawad 2009). In this study, the mean values of $\mathrm{Cu}$ and $\mathrm{Zn}$ in $M$. tuberculata $(2.11 \pm 0.68-2.98 \pm 0.34$ and $4.57 \pm 0.81-8.11 \pm 1.35 \mu \mathrm{g} / \mathrm{g}$, respectively) as well as those in Lanistes varicus $(1.87 \pm 0.55-3.11 \pm 0.45$ and $9.40 \pm 1.41-12.51 \pm 0.44 \mu \mathrm{g} / \mathrm{g}$, respectively) were comparatively much lower than similar ecotoxicological studies of gastropods in Nigeria.

\section{Conclusions}

In conclusion, concentrations of $\mathrm{Cu}$ and $\mathrm{Zn}$ in the benthic sediment and the gastropod species were within safe limits and indicative of an unimpacted freshwater system. In view of this study and similar ecotoxicological studies in Nigeria, it may be concluded that the underlain carbonaceous rocks of the river as well as its riparian forest and regulated human activities in the grove have all contributed to a freshwater system with very low heavy metal concentrations. Thus, it could be inferred that the protected nature of the river reduces its toxicological risk considerably and the concentrations of $\mathrm{Cu}$ and $\mathrm{Zn}$ pose no threat to its biota.

\section{Acknowledgements}

This study was carried out with the kind approval of the National Commission for Museums and Natural Monument and the cooperation of their out-station staff at the Osun-Osogbo Sacred Grove, Nigeria.

\section{Funding}

This research did not receive any specific grant from funding agencies in the public, commercial or not-for-profit sectors.

\section{Authors' contributions}

EOA designed the project, took part in the field study and wrote the manuscript. GOO was responsible for the laboratory analysis and wrote some aspect of the manuscript. OGO took part in the field study and laboratory analysis. AVA took part in the field study and laboratory analysis. All authors read and approved the final manuscript.

\section{Ethics approval}

All applicable international, national and/or institutional guidelines for the care and use of animals were followed.

\section{Competing interests}

The authors declare that they have no competing interests.

\section{Publisher's Note}

Springer Nature remains neutral with regard to jurisdictional claims in published maps and institutional affiliations.

\section{Author details}

'Department of Zoology, Obafemi Awolowo University, lle-lfe, Nigeria. ${ }^{2}$ Department of Chemistry and Industrial Chemistry, Bowen University, Iwo, Nigeria. ${ }^{3}$ Department of Biological Sciences, Bowen University, Iwo, Nigeria. ${ }^{4}$ Institute of Ecology and Environmental Studies, Obafemi Awolowo University, lle-Ife, Nigeria.

Received: 12 May 2017 Accepted: 25 July 2017

Published online: 24 August 2017

\section{References}

Abd El Gawad SSI (2009) The mollusk gastropod Lanistes carinatus (Olivier, 1804) as a biomonitor for some trace metals in the Nile River. International Journal of Zoological Research 5(3):115-125

Adekoya JA, Williams AB, Ayejuyo OO (2006) Distribution of heavy metals in sediments of Igbede, Ojo and Ojoro Rivers of Lagos, Nigeria. Environmentalist 26:277-280

Adewunmi CO, Becker W, Kuehmast O, Oluwole F, Dorfler G (1996) Accumulation of copper, lead and cadmium in freshwater snails in southwestern Nigeria. Sci Total Environ 193:69-73

Akhan JC, Abdulrahman Fl, Sodipo OA, Ochanya AE, Askira YK (2010) Heavy metals in sediments from River Ngada, Maiduguri Metropolis, Borno State, Nigeria. Journal of Environmental Chemistry and Ecotoxicology 2(9):131-140

Akindele EO, Adeniyi IF (2013) A study of the physico-chemical water quality, hydrology and zooplankton fauna of Opa Reservoir catchment area, lle-lfe, Nigeria. Afr J Environ Sci Technol 7(5):192-203

Akinpelu Al, Areo A (2007) The snakes of Osun Grove: a world heritage site in Osogbo, Nigeria. Rev Biol Trop 55:717-721

AOAC (Association of Official Analytical Chemists) (1990) Official methods of analysis. Association of Official Analytical Chemists. Arlington, Virginia

Campbell PGC, Tessier A (1996) Ecotoxicology of metals in aquatic environments: geochemical aspects. In: Newman MC, Jagoe CH (eds) Ecotoxicology: a hierarchical treatment. Lewis Publishers, Boca Raton

Canadian Council of Ministers of the Environment (1999a) Copper. In: Canadian CouEncil of Ministers of the Environment (ed) Canadian environmental quality guidelines: Canadian sediment quality guidelines for the protection of aquatic life. Canadian Council of Ministers of the Environment, Winnipeg

Canadian Council of Ministers of the Environment (1999b) Zinc. In: Canadian Council of Ministers of the Environment (ed) Canadian environmental quality guidelines: Canadian sediment quality guidelines for the protection of aquatic life. Canadian Council of Ministers of the Environment, Winnipeg

Chapman D, Kimstach V (2006) Selection of water quality variables. In: Chapman $D$ (ed) Water quality assessments: a guide to the use of biota, sediments and water in environmental monitoring. Chapman \& Hall, London

Dachs J, Mejanelle $L$ (2010) Organic pollutants in coastal waters, sediments, and biota: a relevant driver for ecosystems during the anthropocene? Ecological Studies 204:287-304

Environment Canada (1998) Canadian sediment quality quidelines for copper: supporting document. Environmental Conservation Service, Ecosystem 
Science Directorate, Science Policy and Environmental Quality Branch, Guidelines and Standards Division, Ottawa

Forstner W, Wittmann GTW (1981) Metal pollution in the aquatic environment. Springer-Verlag, New York

Friedrich G, Chapman D, Beim A (1996) The use of biological material. In: Chapman D (ed) Water quality assessments: a guide to the use of biota, sediments and water in environmental monitoring. Chapman \& Hall, London Gimeno-Garcia E, Andreu V, Boluda R (1996) Heavy metals incidence in the application of inorganic fertilizers and pesticides to rice farming soils. Environ Pollut 92(1):19-25

Government of Saskatchewan (2008) Zinc for private water and health regulated public water supplies http://www.saskh2o.ca/waterinformationfactsheet_ drinking_private health.asp

Hedrick JB (2001) Rare earths. US Geological Survey Minerals Yearbook, USA Iwegbue CMA, Nwajei GE, Arimoro FO (2007) Assessment of contamination by heavy metals in sediments of Ase River, Niger Delta, Nigeria. Res $J$ Environ Sci 1:220-228

Jaagumagi R (1988) The in-place pollutants program: benthic invertebrate studies results. Ontario Ministry of the Environment, Water Resources Branch, Aquatic Biology Section, Toronto

Kibria G, Yousuf Haroon AK, Nugegoda G, Rose G (2010) Climate change and chemicals: environmental and biological aspects. New India Publishing Agency, New Delhi

Kibria G, Hossain MM, Mallick D, Lau TC, Wu R (2016) Monitoring of meta pollution in waterways across Bangladesh and ecological and public health implications of pollution. Chemosphere 165:1-9

Malle KG (1992) Zink in der Umwelt. Acta Hydrochim Hydrobiol 20(4):196-204

Muir DCG, de Wit CA (2010) Trends of legacy and new persistent organic pollutants in the circumpolar arctic: overview, conclusions, and recommendations. Sci Total Environ 408:3044-3051

Onwuemesi FE, Onuba LN, Chiaghanam Ol, Anudu GK, Akanwa AO (2013) Heavy metal accumulation in fish of Ivo River, Ishiagu, Nigeria. Research Journal of Environmental and Earth Sciences 5(4):189-192

Onwuka GI (2005) Food analysis and instrumentation: theory and practice. Naphthali Prints, Lagos

Onyekwelu JC, Olusola JA (2014) Role of sacred grove in in-situ biodiversity conservation in rainforest zone of south-western Nigeria. J Trop For Sci 26:5-15

Rainbow PS (2007) Trace metals bioaccumulation: models, metabolic availability and toxicity. Environ Int 33:576-582

Ray GC, McCormick-Ray J (2014) Marine conservation: science, policy and management. John Wiley \& Sons, Ltd, West Sussex

Shuhaimi-Othman M, Nur-Amalina R, Nadzifah Y (2012) Toxicity of metals to a freshwater snail, Melanoides tuberculata. Sci World J 2012:125785

Tyokumbur ET, Okorie TG (2014) Bioconcentration of trace metals in the freshwater snail Melanoides tuberculata (Mollusca: Thiaridae) from Alaro stream ecosystem of South West Nigeria. Advances in Bioscience and Bioengineering 2(1):51-65

USEPA Report (1996) Recent developments for in-situ treatment of metals contaminated in soils. United States Environmental Protection Agency, USA

Uzairu A, Harrison GFS, Balarabe ML, Nnaji JC (2009) Concentration levels of trace metals in fish and sediment from Kubanni River, Northern Nigeria. Bull Chem Soc Ethiop 23(1):9-17

Wangboje OM, Ikhuabe AJ (2015) Heavy metal content in fish and water from River Niger at Agenebode, Edo State, Nigeria. Afr J Environ Sci Technol 9(3):210-217

\section{Submit your manuscript to a SpringerOpen ${ }^{\circ}$ journal and benefit from:}

- Convenient online submission

- Rigorous peer review

- Open access: articles freely available online

- High visibility within the field

- Retaining the copyright to your article 